provide smudges against insect pests and for other purposes. In some cases through carelessness, in some cases inevitably through the nature of the fires set, fire thus used extended beyond the intended area and became a general conflagration, often extending over many square miles. The arrival of the white man did nothing to ease the situation as he used fires for all the same purposes as the Indian and added several more to the list such as burning to improve forage for livestock, to obtain dry fuelwood and to destroy the forest to facilitate prospecting.

Professor Lutz concludes that, "In the boreal forest there were many fires whose causes are unknown. Some of these must have resulted from lightning but it is likely that most of them were caused by man, either aboriginal or white.

It is probable that there have been fires in the northern forests ever since there were forests to burn. Destruction of timber has been enormous but the boreal forest has generally shown a remarkable capacity to recover, to rise again phoenix-like from its ashes."

This is a very interesting study of a subject on which the literature is rather scant. It is of equal interest to Canadians and Americans because so many of the references are to Canadian sources and most of the conclusions apply equally to the boreal forests of Canada and Alaska. One is immensely impressed with the extensive survey of the literature of early northern exploration which Professor Lutz has undertaken to secure the information for this work; indeed his list of "References Cited" makes an excellent bibliography of this subject and I would value the volume for this reason alone.

\title{
CURRENT PUBLICATIONS \\ GENERAL
}

Great Britain. 1959. Thirty-ninth annual report of the Forestry Commissioners, 1958. British Forestry Commission.

Great Britain. 1959. Report on Forest Research, 1958, Forestry Commission. New Zealand. 1959. Report of the Director of Forestry.

\section{MANAGEMENT}

Canadian Forestry Association of B.C. 1959. Fire Control Notes (lectures presented during the fourth annual fire control course, January 1959.) $198 \mathrm{pp}$.

Gedney, D. R., D. E. Martin and F. A. Johnson. 1959. Specifications for calculating several equations of relationship between two variables on a type 650 electronic computer. Pacific N.W.F.R.E.S. Portland, Oregon, 15 pp.

Rawlings, G. B. 1959. Problems of forest entomology in exotic forests in New Zealand. N.Z. For. Res. Note 22, 6 pp.

Reynolds, R. R. 1959. Eighteen Years of Selection Timber Management on the Crossett Experimental Forest. Tech. Bull. 1206 U.S.D.A., For. Serv. Washington, D.C., 68 pp.

Silen, R. R. and L. R. Woike. 1959. The Wind River Arboretum from 1912 to 1956. Res. Pap. 33. Pacific N.W.F.R.E.S. Portland, Ore., 50 pp.

Stage, A. R. 1959. Site Index Curves for Grand Fir in the Inland Empire. Res. Note 71. Intermountain F.R.E.S., Ogden, Utah, 4 pp. 
Wilton, W. C. 1959. Forest Types of the Grand Lake and Northwestern Lake Melville areas of Labrador. Tech. Note 83, For. Res. Div. Dept. N.A. \& N.R., Ottawa, $30 \mathrm{pp}$.

\section{Silviculture}

Brinkman, K. A. 1959. Killing Oak Brush a Tricky Business. Tech. Pap. 165. Central States F.E.S., Columbus, O. 9 pp.

Boyce, S. G. and D. J. Neebe. 1959. Trees for Planting on Strip-Mined Land in Illinois. Tech. Pap. 164. Cent. States F.E.S., Columbus, O., 33 pp.

Dunn. S. and R. Eggert. 1959. Propagation of Woody Plants. Sta. Bull. 465. Agric. Ex. Sta. Univ. of New Hampshire, Durham, N.H., 12 pp.

Ehrenreich, J. H. 1959. Releasing Understory Pine Increased Herbage Production. Sta. Note 139, Cent. States F.E.S., Columbus, O., 2 pp.

Engle, L. G. and F. B. Clark. 1959. New Rodent Repellents fail to work on acorns and walnuts. Sta. Note 138, Cent. States F.E.S., Columbus, O., 2 pp.

Hallin, W. E. 1959. Release of Sugar Pine Seedlings and Saplings by Harvest Cutting. Res. Note 179. Pacific N.W.F.R.E.S., Portland, Oregon, 3 pp.

Jarvis, J. M. 1960. Forty-five years growth on the Goulais River Watershed. Tech. Note 84. For. Res. Div. Dept. N.A. \& N.R., Ottawa, 31 pp.

Logan, K. T. 1959. Some Effects of Light on Growth of White Pine Seedlings. Tech. Note 82. For. Res. Div. Dept. N.A. \& N.R. Ottawa, 20 pp.

Madison R. W. 1959. Growth and Survival of a Sitka Spruce Plantation in Coastal Oregon. Res. Note 178. Pacific N.W.F.R.E.S., Portland, Oregon, $6 \mathrm{pp}$.

Stiell, W. M. 1959. Seeding and Planting Red and White Pine. Tech. Note 80, For. Res. Div. Forestry Branch, Dept. N.A. \& N.R., 15 pp.

Stiell, W. M. 1959. Intermediate Cuttings in Red and White Pine Plantations. Tech. Note 81. For. Res. Div. For. Br. Dept. N.A. \& N.R., Ottawa, 25 pp.

Williams, R. D. and T. W. Beers, 1959. Seed Source Affects Height Growth of Planted Jack Pine. Sta. Note 137. Cent. States F.E.S., Columbus, O., 2 pp.

\section{UTILIZATION}

Besley, L. 1959. Relationships between Wood Fibre Properties and Paper Quality. Tech. Rep. 156. Woodlands Res. Index No. 114, P.P.R.I.C., Montreal, 19 pp.

Eades, H. W. and J. W. Roff. 1959. Red Heart Stain of Lodgepole Pine Logs in the Southern Interior of British Columbia. V-1025 For. Prod. Labs. Br. Dept. N.A. \& N.R., Ottawa, 11 pp.

Hutchison, S. B. 1959. Production-Distribution Trends and Freight Rates as They Affect Mountain States Lumber Producers. Res. Pap. 59, Intermountain F.R.E.S., Ogden, Utah, 13 pp.

Mendel, J. J. 1959. Veneer-Log Production and Consumption in the Central States 1958. Tech. Paper 166, Cent. States F.E.S., Columbus, O., 5 pp.

Mendel, J. J. 1959. Cooperage logs and bolts-Production and Consumption in the Central States 1958. Sta. Note 140. Cent. States F.E.S., Columbus, O., $2 \mathrm{pp}$.

Wilson, A. K. 1959. Pole Production in Northern Rocky Mountains Slumps in 1958. Res. Note 72, Intermountain F.R.E.S., Ogden, Utah, 4 pp. 